from Dr. Ros on the raising of the fatigue limit by improving the perfection of the surface of machine parts. The writer presented a note on fretting oxidation, suggesting that it was more likely that oxygen was forced into combination with iron by the very high local pressures in bearings, and that the oxide was then stripped off, than that metal was first romoved and then oxidized.

After the close of the meeting, some of the foreign visitors had the opportunity of inspecting the fine new Laboratoire Central des Traitements Chimiques at Vitry-sur-Seine, established by the Centre National de la Recherche Scientifique and occupying a large new building. Much of the very fine equipment was hidden during the German oecupation. There is a staff of energetic young workers under the direction of Prof. Chaudron. The high quality of the microscopical work is notable, especially in the study of the light metals. Electrolytically polished surfaces, strained to produce slip bands and then etched, show sharp etch figures indicating the orientation. Such figures can also be used to demonstrate the mosaic structure in single metallic crystals. Apparatus for estimating oxygen in steel by the method of hot extraction in a vacuum, similar to that of the National Physical Laboratory but employing radio frequencies, also attracted attention. Both from the quality of the original contributions presented and as indicating a resumption of collaboration between France and other countrios, the conference must be regarded as highly successful.

C. H. DESOH.

\section{AVIAN EVOLUTION IN NEW ZEALAND}

\section{By DR. H. BARRACLOUGH FELL University College, Wellington}

\begin{abstract}
LTHOUGH the Ratite birds of New Zealand have been the subject of intense osteological study ever since Owen received the first bone of Dinornis, a considerable interval has elapsed since the Carinate orders received the attention which they warrant. Some twelve years ago Lowe in an exten. sive memoir ${ }^{1}$ gave reasons for believing the penguins to have arisen independently from reptilian ancestors, and to have specialized from the beginning as aquatic animals. More recently, the same writer reaffirmed this view in a paper ${ }^{2}$ in which he discounts the belief that Archoeopteryx and Archoeornis were birds. In other recent papers Lowe has presented a considerable amount of anatomical data supporting the conclusion that the Ratites are of primitive stock which never possessed the power of flight, nor consequently the keeled sternum ${ }^{3,4}$. These papers, however, did not deal particularly with evidence from New Zea. land, though the deductions are of special interest there. It is therefore certain that zoologists will welcome the two important papers by Dr. W. R. B. Oliver, director of the Dominion Museum, in which he brings to bear upon the problem of the phylogeny of New Zealand birds the evidence he has obtained from a close study of their skulls ${ }^{5,6}$.

Dr. Oliver tackles the problem from the aspect of comparative anatomy of living and recently extinct types, for indeed, as he points out, so little is known of early precursors that no other course is at present open. The splendid series of photographs (by J. T. Salmon) and the line illustrations of cranial bones,
\end{abstract}

with the accompanying descriptions, are in themselves a worthy contribution to the subject, while the phylogenetic conclusions will warrant the close attention of those interested in ornithology. In a review of this length it is, of course, impossible to do justice to the paper ; but some of the more interesting conclusions may be indicated briefly, particularly where these diverge from views previously expressed by overseas writers.

Gregory and Murphy? have taken the view that the Ratites arose from Proto-carinate ancestors. Archey ${ }^{8}$, while supporting this view, admits, however, the primitive nature of their palate. Oliver, on the other hand, regards the Ratites as having arisen side by side with the Proto-carinates, both being derived from neornithid stock. He regards the vomer in the moas as the most primitive type found in birds, and in connexion with the vexed problem of the evolution of the Ratite sternum, his views are worth quoting. Pointing out that there is no evolutionary sequence in which Ratite sterna can be arranged, he states : "It is more than doubtful that this (keel-less) condition could be attained by the loss, through disuse of the pectoral muscles, of a keel such as is found in Carinate birds. For in those genera in which the keel has been reduced almost to vanishing point, namely, Aptornis, Notornis, Strigops and Chemiornis, there are rudiments of the keel and, in Aptornis and Notornis, considerable narrowing of the body of the sternum. These examples show the end of a cycle of evolutionary growth and are unlike the type found in Ratites, which consequently may be regarded as representing the early stages of the cycle. It is in this way that I think the evidence for the Ratite keelless sternum being a primitive form should be stated."

Dr. Oliver disagrees with Lowe's deductions on the primitive nature and independent evolution of the penguins. $\mathrm{He}$ points out that the palatine anatomy of the penguins he has examined would suggest an advanced (that is, late) stage of development, especially in the case of the vomer. He suggests that the apparently primitive features of these birds may well be due to secondary simplification. He also differs from some other zoologists in that he regards the rails and cranes as having arisen from the same stock. Thus he is able to retain Aptornis in the latter order, accounting for such crane-like characters as it shows through a common ancestry. On skeletal, characters he concludes that Aptornis diverged early from the remainder of the rails, the latter giving rise in turn to Notornis, and as a separate branch, the gallinules.

In adopting the osteological features of the palate as a basis of classification, Oliver finds that the sixteen genera of New Zealand Passeriformes fall into five main groups. Evidence is presented for believing the native thrushes (Turnagra) to be less closely related to the Turdidæ than was formerly thought, being allied rather to the crow shrikes. Another interesting proposition advanced with supporting osteological evidence is that the parrots may be more closely related to the Coraciiformes than to the Accipitriformes.

\footnotetext{
${ }^{1}$ Lowe, P. R., Proc. Zool. Soc. Lond., 2, 483 (1933).

${ }^{2}$ Lowe, P. R., Ibis, 517 (1944).

${ }^{3}$ Lowe, P. R., Proc. Zool. Soc. Lond., B, 112, 1 (1942).

${ }^{4}$ Lowe, P. R., Ibis, 37 (1944).

${ }^{5}$ Oliver, W. R. B., Emu, 45, 55 (1945).

${ }^{6}$ Oliver, W. R. B., Emu, 45, 119 (1945).

'Gregory, W. K., and Murphy, R. C., Proc. Linn. Soc. New York, 45 (1934).

"Archey, G., Bull. Auck. Inst. Mus., 1 (1941).
} 